\title{
Effect of Temperature and Gas Flow Rate on $\mathrm{CO}_{2}$ Capture
}

\author{
Ayse Gul ${ }^{1 *}$ (1), Umran Tezcan Un ${ }^{2}$ (1)
}

${ }^{1}$ Department of Civil Engineering, Abdullah Gul University, Kayseri, TURKEY

${ }^{2}$ Department of Environmental Engineering, Eskisehir Technical University, Eskisehir, TURKEY

*Corresponding Author: ayse.gul@agu.edu.tr

Citation: Gul, A. and Tezcan Un, U. (2022). Effect of Temperature and Gas Flow Rate on $\mathrm{CO}_{2}$ Capture. European Journal of Sustainable Development Research, 6(2), em0181. https://doi.org/10.21601/ejosdr/11727

\section{ARTICLE INFO}

Received: 30 Jun. 2021

Accepted: 15 Dec. 2021

\begin{abstract}
In this study, the removal of carbon dioxide $\left(\mathrm{CO}_{2}\right)$ that has a huge contribution to global warming from gas emissions was performed using absorption method. Effect of operational parameters such as temperature and gas flow rate on the absorption capacity $\left(\mathrm{g} \mathrm{CO}_{2} / \mathrm{kg}\right.$ solvent and mol $\mathrm{CO}_{2} / \mathrm{mol} \mathrm{MEA}$ ) was investigated in a bubble column reactor with a semi-batch operation. The monoethanolamine (MEA) was used as a solvent and absorption capacity was determined at different gas flow rates $(2.5$ and $5 \mathrm{~L} / \mathrm{min})$ and temperatures $\left(25-35-45^{\circ} \mathrm{C}\right)$. Because of the study, absorption capacities of $74.71 \mathrm{~g} \mathrm{CO}_{2} / \mathrm{kg}$ MEA and $0.51 \mathrm{~mol} \mathrm{CO}_{2} / \mathrm{mol} \mathrm{MEA}$ were obtained at $5 \mathrm{~L} / \mathrm{min}$ gas flow rate, $25^{\circ} \mathrm{C}$ and $20 \%$ solvent concentration. The absorption capacity increases as the temperature decreases and as the flow rate increases. Because of the study, it can be concluded that the capture of $\mathrm{CO}_{2}$ into the MEA solution at bubble column can be successfully achieved with high absorption capacity.
\end{abstract}

Keywords: MEA, absorption capacity, bubble column, $\mathrm{CO}_{2}$ fixation

\section{INTRODUCTION}

Because of the increasing industrialization and the need for energy in the world, our dependence on fossil fuels has increased, which causes an increase in carbon dioxide concentration in the atmosphere. According to NASA, over the past 171 years, the global average amount of carbon dioxide is raised with human activities by $48 \%$ above pre-industrial levels found in 1850 and hit a record high in 2021 as 416 parts per million (NASA, 2021). Carbon dioxide $\left(\mathrm{CO}_{2}\right)$ is an important greenhouse gas that causes global warming effects (NASA, 2021). To reduce global warming, reduction of $\mathrm{CO}_{2}$ emissions is critical and considering this energy needs supplied from fossil fuels, CCS (carbon capture storage) is the best way to maintain $\mathrm{CO}_{2}$ level under control.

Various methods have been studied to reduce postcombustion $\mathrm{CO}_{2}$ emissions, such as chemical absorption (Heydarifard et al., 2020; Pang et. al., 2021), physical absorption (Elhambakhsh et al., 2020), membrane separation (Widakdo et al., 2021; Yu et al., 2021), adsorption (Wu et al., 2021), cryogenic separation (Bi and Ju, 2021), algal system (Judd et al., 2015). In these processes, chemical absorption is extensively used for the removal of $\mathrm{CO}_{2}$ from flue gas by chemical reaction with a solvent (Chen et al., 2008). The drawbacks of $\mathrm{CO}_{2}$ adsorption method include adsorption mechanism only occurring on the material surface, and that regeneration would require a stoppage to the adsorption process. Cryogenic $\mathrm{CO}_{2}$ separation also requires significant amounts of energy for the cooling of $\mathrm{CO}_{2}$ down to its liquefaction temperature at $78.5^{\circ} \mathrm{C} . \mathrm{CO}_{2}$ capture with a membrane is an interesting field of study but it still faces challenges in the form of the unavoidable tradeoff between permeability and selectivity, as well as poor resistance towards acid gases (Wibowo et al., 2021).

Absorption-based technology is the most widely used worldwide, accounting for $64 \%$ of total $\mathrm{CO}_{2}$ capture capacity in these facilities and is used in $72 \%$ of the facilities. Aminebased solvent alone is used in $69 \%$ of the facilities, accounting for $55 \%$ of total $\mathrm{CO}_{2}$ capture capacity. The popularity of aminebased absorbent, is most due to its high absorption efficiency, low energy consumption, high economic value, and simple operation (Peng et al., 2012; Wibowo et al., 2021). In the field of $\mathrm{CO}_{2}$ absorption, innovations can be made on the searching solvents and scrubber types. Several scrubbers are used to capture $\mathrm{CO}_{2}$, such as packed bed column, sieve tray column and bubble column. Bubble columns have several advantages, such as high mass and heat transfer rates, simple operation without any moving parts and the flexibility to adjust various residence time requirements.

Various solvents are used in the bubble column for $\mathrm{CO}_{2}$ absorption based on published data. Heydarifard et al. focus on $\mathrm{CO}_{2}$ reactive absorption using Piperazine aqueous solutions in a stirrer bubble column (Heydarifard et al., 2018). Bai and Yeh (1997) studied the $\mathrm{CO}_{2}$ capture by ammonia in bubble column reactor. In a stirred bubble column, Pashaei et al. (2017) investigated the solubility and chemical absorption rate of 
carbon dioxide into aqueous solutions of diethanolamine. Monoethanolamine (MEA) is frequently used to evaluate experimental setups and as a reference. Aronu et al. (2011) and Maneeintr et al. (2009) obtained $76 \mathrm{~g} \mathrm{CO}_{2} / \mathrm{kg}$ MEA and $80 \mathrm{~g}$ $\mathrm{CO}_{2} / \mathrm{kg}$ MEA absorption capacities using bubble columns at $20 \%$ MEA and $40^{\circ} \mathrm{C}$, respectively. Aronu et al. (2011) obtained $0.516 \mathrm{~mol} \mathrm{CO}_{2} / \mathrm{mol} \mathrm{MEA}$ absorption capacity at $2.5 \mathrm{M}$ (\%15) MEA, $40^{\circ} \mathrm{C}$ temperature and $4.84 \mathrm{kpa}$ partial pressure of $\mathrm{CO}_{2}$.

In this study, the absorption capacity of MEA solution was investigated in a bubble column reactor. The main objective of this study is to determine the effect of temperature and gas flow rate on absorption capacity given as $\mathrm{g} \mathrm{CO}_{2} / \mathrm{kg}$ solvent and $\mathrm{mol} \mathrm{CO} / \mathrm{mol} \mathrm{MEA}$.

\section{REACTION MECHANISM}

MEA is an important solvent in the $\mathrm{CO}_{2}$ removal process because it reacts quickly with carbon dioxide due to its primary amine characteristics (Maceiras et al., 2008).

Different reaction mechanisms are proposed based on the number of amine functionality. Two different mechanism named zwitterion and termolecular mechanism is proposed to describe reaction mechanisms between $\mathrm{CO}_{2}$ and primary amine $\left(\mathrm{RNH}_{2}\right)$ solutions. Because of the reaction between $\mathrm{CO}_{2}$ and MEA solution, the carbamate ( $\left.\mathrm{RNHCOO}^{-}\right)$is formed in two steps according to the zwitterion mechanism, in one step according to the termolecular mechanism.

In the zwitterion mechanism, firstly the zwitterion ion $\left(\mathrm{RNH}_{2}{ }^{+} \mathrm{COO}^{-}\right)$is formed (Eq. 1) as an intermediate and then it is deprotonated (Eq. 2) to form carbamate $\left(\mathrm{RNHCOO}^{-}\right)$. In these reactions, $\mathrm{B}$ could be $\mathrm{CO}_{3}{ }^{2-}, \mathrm{HCO}_{3}{ }^{-}$, amine, $\mathrm{H}_{2} \mathrm{O}$, or $\mathrm{OH}^{-}$ (Ramezani et al., 2021).

$\mathrm{CO}_{2}+\mathrm{RNH}_{2} \leftrightarrow \mathrm{RNH}_{2}^{+} \mathrm{COO}^{-}$

$\mathrm{RNH}_{2}^{+} \mathrm{COO}^{-}+\mathrm{B} \leftrightarrow \mathrm{RNHCOO}^{-}+\mathrm{BH}^{+}$

According to the termolecular mechanism, $\mathrm{CO}_{2}$ react with MEA, as follow (Eq. 3):

$\mathrm{CO}_{2}+\mathrm{RNH}_{2}+\mathrm{B} \leftrightarrow \mathrm{RNHCOO}^{-}+\mathrm{BH}^{+}$

Additionally, $\mathrm{CO}_{2}$ reacts with $\mathrm{H}_{2} \mathrm{O}$ as given in Eq. (4-6). But overall contribution of these reactions can be negligible in the presence of MEA (Ramezani et al., 2021):

$$
\begin{aligned}
& \mathrm{H}_{2} \mathrm{O}+\mathrm{CO}_{2} \leftrightarrow \mathrm{H}^{+}+\mathrm{HCO}_{3}^{-} \\
& \mathrm{H}_{2} \mathrm{O} \leftrightarrow \mathrm{H}^{+}+\mathrm{OH}^{-} \\
& \mathrm{HCO}_{3}{ }^{-} \leftrightarrow \mathrm{H}^{+}+\mathrm{CO}_{3}{ }^{2-}
\end{aligned}
$$

\section{MATERIALS AND METHOD}

\section{Calculation of Absorption Capacity}

The absorption capacity is the maximum amount of pollutant absorbed per amount of solvent. The absorption capacity of continuous system can be calculated using the effluent $\mathrm{CO}_{2}$ concentration vs time graph. The area in Figure 1 between the curves representing the inlet and outlet concentrations of $\mathrm{CO}_{2}$ is used to determine the amount of total absorbed $\mathrm{CO}_{2}$. The upper line is actually the $\mathrm{CO}_{2}$ concentration in the inlet, which was kept constant during a single run. At

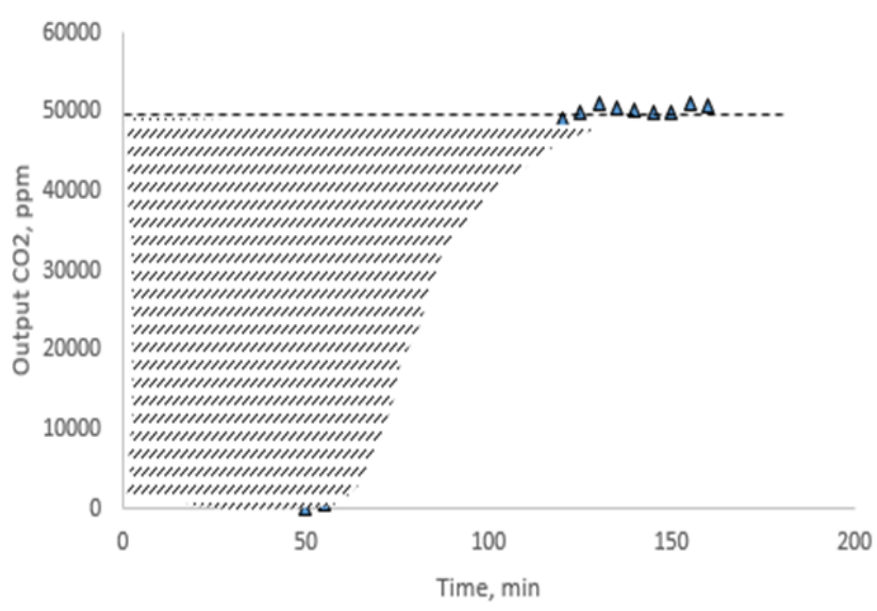

Figure 1. A sample of the $\mathrm{CO}_{2}$ concentration profile at the output

the outlet, concentration changes alongside the saturation of the MEA absorbent solution. The difference between these two values shows the absorbed amount. The input flow rate of $\mathrm{CO}_{2}$ can be calculated using the total flow rate and inlet $\mathrm{CO}_{2}$ concentration. The outlet flow rate of $\mathrm{CO}_{2}$ can be calculated using a fixed flow rate of $\mathrm{N}_{2}$, which is an inert compound and effluent $\mathrm{CO}_{2}$ concentration. Eq. (7) was used to calculate the $\mathrm{CO}_{2}$ outlet flow rate:

$$
Q_{\mathrm{CO}_{2_{\text {out }}}}=Q_{\text {total }_{\text {in }}} \times y_{N_{2 \text { in }}}\left(\frac{y_{\mathrm{CO}_{2} \text { out }}}{} y_{N_{2_{\text {out }}}}\right)
$$

In this equation, $Q_{\mathrm{CO}_{2} \text { out }}$ is the outlet flow rate $(\mathrm{l} / \mathrm{min})$; $Q_{\text {total }_{\text {in }}}$ is the total flow rate $(1 / \mathrm{min}) ; y_{N_{2 i n}}$ is $\mathrm{N}_{2}$ mole fraction in the gas inlet; $y_{\mathrm{CO}_{2 o u t}}$ is $\mathrm{CO}_{2}$ mole fraction in the gas outlet; $y_{N_{2} \text { out }}$ is $\mathrm{N}_{2}$ mole fraction in the gas outlet.

The volumetric flow rates are converted to molar mass flow rate using conversion factors and assuming an ideal gas equation of state where each mole of gas occupies 22.4 liters at standard temperature $(273 \mathrm{~K})$ and pressure (1 atm). Then, the effluent concentration ( $\mathrm{ppm}$ )-time graph can be replotted for mass flow rate-time. The rate of absorbed $\mathrm{CO}_{2}$ at each reading interval is then calculated using Eq. (8):

$$
R_{\mathrm{CO}_{2}}=\dot{M}_{\mathrm{CO}_{2} \text { in }}-\dot{M}_{\mathrm{CO}_{2} \text { out }}
$$

where, $\mathrm{RcO}_{2}$ is the rate of absorbed $\mathrm{CO}_{2}(\mathrm{l} / \mathrm{min}), \dot{M}_{\mathrm{CO}_{2} \text { in }}$ is the mass of absorbed $\mathrm{CO}_{2}$ in the gas inlet, and $\dot{M}_{\mathrm{CO}_{2} \text { out }}$ is the mass of absorbed $\mathrm{CO}_{2}$ in the gas outlet.

The amount of absorbed $\mathrm{CO}_{2}$ for each time interval was calculated using Eq. (9):

$$
M_{\mathrm{CO}_{2 a b}}=R_{\mathrm{CO}_{2}} \times\left(t_{2}-t_{1}\right)
$$

where, $\mathrm{Mco}_{2}$ is the mass of absorbed $\mathrm{CO}_{2}\left(\mathrm{~mol} \mathrm{CO}_{2}\right), \mathrm{RcO}_{2}$ is the rate of absorbed $\mathrm{CO}_{2}(\mathrm{l} / \mathrm{min})$, and $\mathrm{t}$ is the time $(0-250 \mathrm{~min})$.

The absorption capacity of the absorbent was calculated using Eq. (10):

$$
\text { Ab. } C a p=\frac{\sum_{1}^{n} M_{C O_{2 a b}}}{M_{M E A}}
$$

where $\mathrm{n}$ is the number of time intervals (250 min), Mco2 is the mass of absorbed $\mathrm{CO}_{2}\left(\mathrm{~mol} \mathrm{CO}_{2}\right)$, and $\mathrm{M}_{\mathrm{MEA}}$ is the mass of MEA (mol MEA) in the solution. The calculations can be done using MS Excel. 


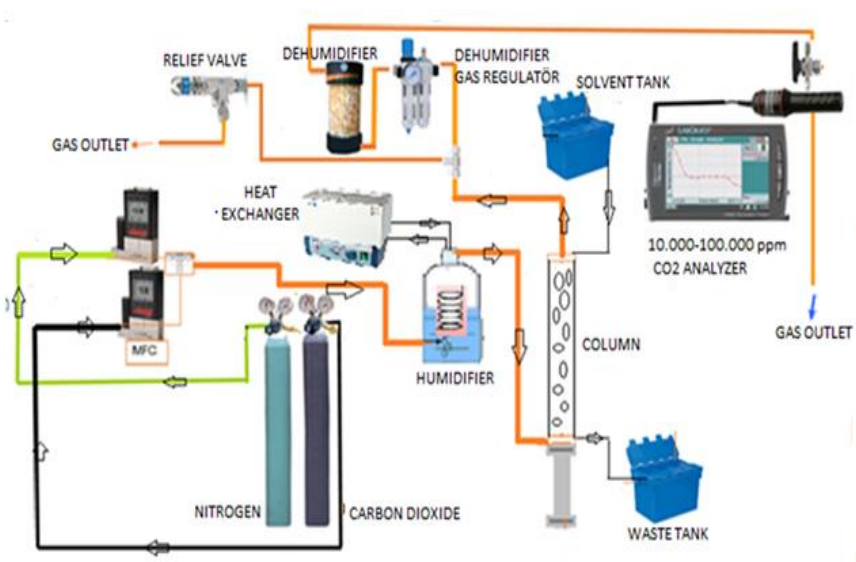

Figure 2. Experimental setup

\section{Chemicals}

MEA was supplied by Sigma (Germany). $\mathrm{N}_{2}$ (>99.99 \%, 200 bar) and $\mathrm{CO}_{2}$ (>99.95\%, 150 bar) gas cylinders were purchased from Oksan gas, Turkey. In all experiments, deionized water was used supplied from the Thermo Scientific (Germany) unit with ultrapure filters.

\section{Experimental Set-up}

In this study, the bubble column absorption column shown in Figure 2 was used. The column has a height of $1.00 \mathrm{~m}$ and diameter of $5.0 \mathrm{~cm}$. The process was performed in semi batch mode where liquid did not flow (batch) and the gas phase was feeding continuously into the solution. Column surrounded with heat jacket that keeps the solution temperature constant in the column. In each experiment, the temperature of the heat jacket was adjusted to the desired temperature $25 \mathrm{~min}$ before the run. However, the MEA solution was heated to the desired temperature on the hot plate and pour into the reactor immediately. A 1L MEA solution is used in each experiment. The gas mixture that consists of $\mathrm{CO}_{2}$ and $\mathrm{N}_{2}$ was prepared using two separate mass flow controllers (ALICAT Scientific Mass Flow Controller, Range:0-10L/min, accuracy; \%0,2 of fullscale). The gas combination (nitrogen and carbon dioxide) is so dry, a continuous flow of gas through the column would cause the solution to evaporate significantly. This is a negative consequence since the solution's concentration and absorption capacity will change. As a result, before introducing gas to the absorption column, a humidifier must be used to saturate the incoming gas stream with humidity. The initial $\mathrm{CO}_{2}$ concentration was adjusted to $50,000 \mathrm{ppm}$ using mass flow controllers. At the beginning of the experiment gas mixture was fed to the $\mathrm{CO}_{2}$ analyzer to ensure its concentration and then fed to the column filled with MEA solution. The gas mixture was bubbled using diffuser in the column and the carbon dioxide concentration of the effluent gas was monitored using an inline $\mathrm{CO}_{2}$ gas analyzer (Vernier, USA). The absorption process continued until there was no further absorption. This was confirmed by the concentration/time profile as shown in Figure 1.

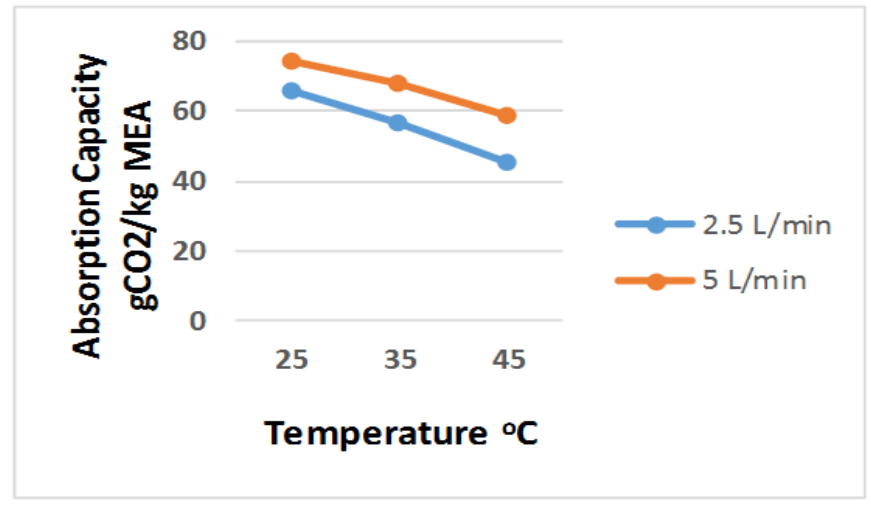

Figure 3. The effect of temperature on the absorption capacity ( $\mathrm{g} \mathrm{CO}_{2} / \mathrm{kg} \mathrm{MEA}$ )

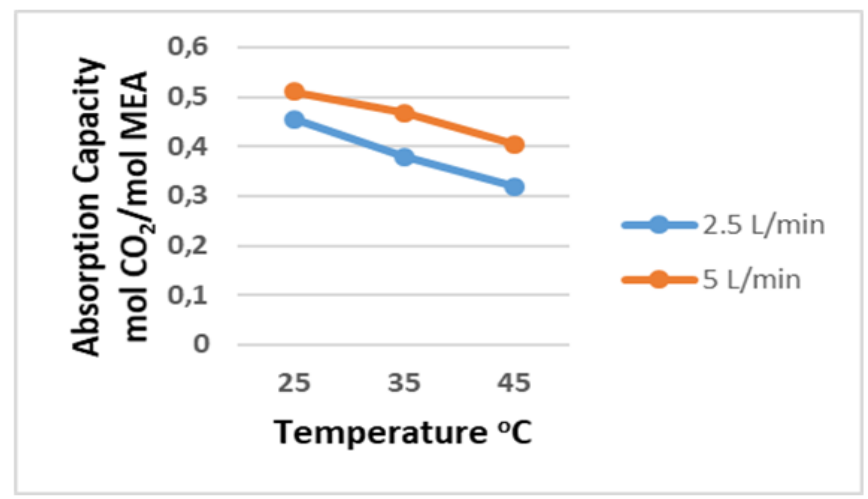

Figure 4. The effect of temperature on the absorption capacity (mol CO$/$ mol MEA)

\section{RESULTS AND DISCUSSION}

\section{The Effect of Temperature on Absorption Capacity}

$\mathrm{CO}_{2}$ absorption capacity is an essential feature for the successful $\mathrm{CO}_{2}$ removal in a bubble column. The absorption capacity can be expressed in two units as mol of $\mathrm{CO}_{2}$ absorbed per mol of amine solution and as $\mathrm{g} \mathrm{CO}_{2}$ absorbed per $\mathrm{kg}$ of amine solution.

The effect of temperature on the absorption capacity is shown in Figure 3 and Figure 4. The absorption capacity of $66.27 \mathrm{~g} \mathrm{CO}_{2} / \mathrm{kg}$ solvent and $0.456 \mathrm{~mol} \mathrm{CO}_{2} / \mathrm{mol} \mathrm{MEA} \mathrm{decreases}$ to $45.67 \mathrm{~g} \mathrm{CO}_{2} / \mathrm{kg}$ solvent and $0.32 \mathrm{~mol} \mathrm{CO} / \mathrm{mol} \mathrm{MEA} \mathrm{with}$ increasing temperature from 25 to $45^{\circ} \mathrm{C}$ when using \%20 MEA solution. This was due to the thermodynamics of the exothermic $\mathrm{CO}_{2}$ absorption system that could cause reversible reactions when the temperature was too high. The increase in temperature could also increase the $\mathrm{CO}_{2}$ vapor pressure over the solution that leads to decrease in the physical solubility of $\mathrm{CO}_{2}$ in the solvent (Tan et al., 2012).

The absorption capacity of $74.71 \mathrm{~g} \mathrm{CO}_{2} / \mathrm{kg}$ MEA was obtained at $5 \mathrm{~L} / \mathrm{min}$ gas flow rate, $25^{\circ} \mathrm{C}$ temperature and $20 \%$ solvent concentration. Similarly, Maneeintr et al. (2009) obtained $80 \mathrm{~g} \mathrm{CO}_{2} / \mathrm{kg}$ MEA absorption capacity at 20\% MEA and $40^{\circ} \mathrm{C}$. Aronu et al. (2011) obtained $76 \mathrm{~g} \mathrm{CO}_{2} / \mathrm{kg}$ MEA absorption capacity at $3.0 \mathrm{M}(\% 20) \mathrm{MEA}, 40^{\circ} \mathrm{C}$ temperature and $15 \mathrm{kpa} \mathrm{CO}_{2}$ with using bubble column. 


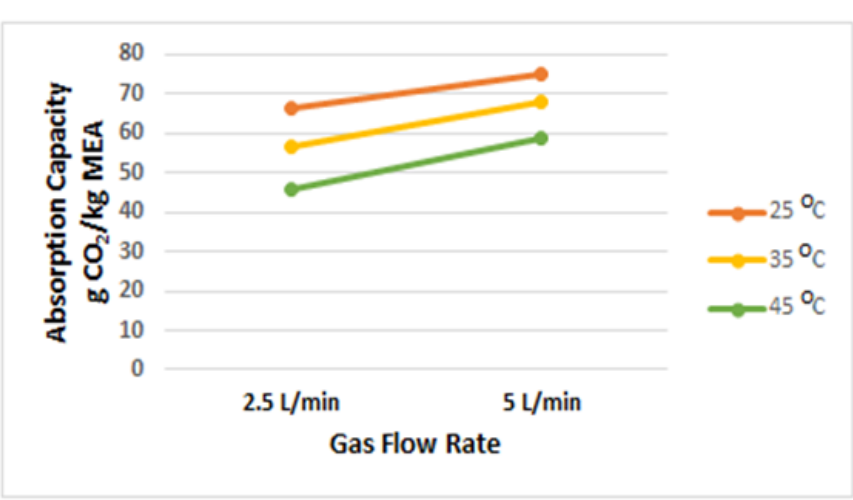

Figure 5. The effect of gas flow rate on the absorption capacity ( $\mathrm{g} \mathrm{CO}_{2} / \mathrm{kg} \mathrm{MEA)}$

\section{The Effect of Gas Flow Rate on Absorption Capacity}

The gas flow rate determines the detention time of the gas component and effects the mixing regime of the solution. The effect of gas flow rate on the absorption capacity is shown in Figure 5 and Figure 6. The amount of $\mathrm{CO}_{2}$ captured per solvent amount increases with increasing gas flow rate. The absorption capacity of $66.27 \mathrm{~g} \mathrm{CO}_{2} / \mathrm{kg}$ solvent and $0.456 \mathrm{~mol}$ $\mathrm{CO}_{2} / \mathrm{mol} \mathrm{MEA}$ was increased to $74.71 \mathrm{~g} \mathrm{CO}_{2} / \mathrm{kg}$ solvent and 0.51 mol CO $2 /$ mol MEA when the gas flow rate increased from 2.5 $\mathrm{L} / \mathrm{min}$ to $5 \mathrm{~L} / \mathrm{min}$. Conway et al. (2015) obtained $0.13 \mathrm{~mol}$ $\mathrm{CO}_{2} / \mathrm{mol}$ MEA absorption capacity at $4 \mathrm{M}$ (\%25) MEA and $3 \mathrm{~L} / \mathrm{min}$ gas flow rate with using wetted-wall column contactor.Aronu et al. (2011) obtained $0.516 \mathrm{~mol} \mathrm{CO} 2 / \mathrm{mol} \mathrm{MEA}$ absorption capacity at $2.5 \mathrm{M}(\% 15) \mathrm{MEA}, 40^{\circ} \mathrm{C}$ temperature and 4.84 kpa partial pressure of $\mathrm{CO}_{2}$ with using bubble column.

With the increasing gas flow rate, detention time of the gas into the solution was decreased. However, a higher flow rate creates turbulent conditions in the column, which is favorable for mass transfer. With increasing gas flow rates, the driving force between $\mathrm{CO}_{2}$ and water is strengthened and more $\mathrm{CO}_{2}$ molecules transfer from the bulk gas phase to the gas-liquid boundary layer, causing an increase in mass-transfer coefficient.

\section{CONCLUSIONS}

In this study, the effect of temperature and gas flow rate on the absorption capacity $\left(\mathrm{g} \mathrm{CO}_{2} / \mathrm{kg}\right.$ solvent and $\mathrm{mol} \mathrm{CO} / \mathrm{mol}$ MEA) determined using bubble column reactor. Experiments were performed at semi-batch mode and 20\% MEA solution was used as a solvent. Because of the study, the following findings were obtained:

1. The absorption capacity increases with the decrease on the temperature. The absorption capacity of $45.67 \mathrm{~g}$ $\mathrm{CO}_{2} / \mathrm{kg}$ solvent and $0.32 \mathrm{~mol} \mathrm{CO} / 2 \mathrm{~mol} \mathrm{MEA}$ increased to $66.27 \mathrm{~g} \mathrm{CO}_{2} / \mathrm{kg}$ solvent and $0.456 \mathrm{~mol} \mathrm{CO}_{2} / \mathrm{mol} \mathrm{MEA}$ when the temperature decreases from $45^{\circ} \mathrm{C}$ to $25^{\circ} \mathrm{C}$.

2. Gas flow rate also effect the absorption capacity positively. The capacity increases from $66.27 \mathrm{~g} \mathrm{CO}_{2} / \mathrm{kg}$ solvent and $0.456 \mathrm{~mol} \mathrm{CO}_{2} / \mathrm{mol} \mathrm{MEA} \mathrm{to} 74.71 \mathrm{~g} \mathrm{CO}_{2} / \mathrm{kg}$ solvent and $0.51 \mathrm{~mol} \mathrm{CO} / \mathrm{mol} \mathrm{MEA}$ when the gas flow rate increases from $2.5 \mathrm{~L} / \mathrm{min}$ to $5 \mathrm{~L} / \mathrm{min}$.

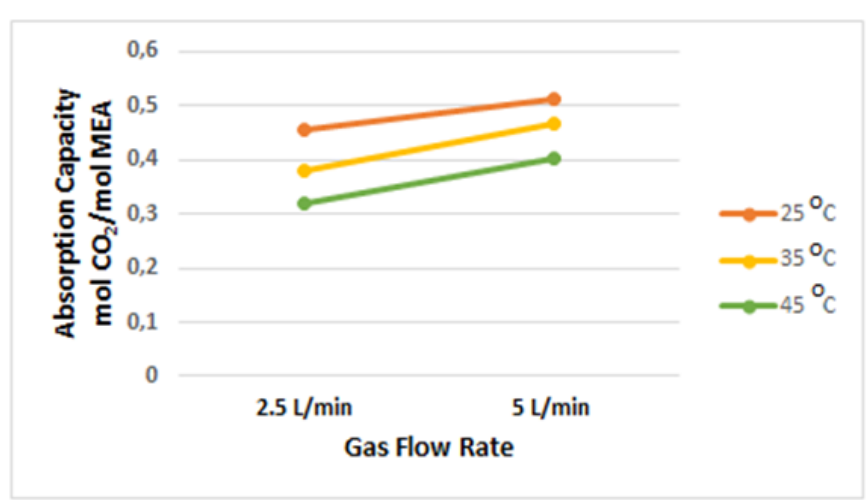

Figure 6. The effect of gas flow rate on the absorption capacity ( $\mathrm{mol} \mathrm{CO} / \mathrm{mol} \mathrm{MEA}$ )

3. Because of the study, absorption capacities of $74.71 \mathrm{~g}$ $\mathrm{CO}_{2} / \mathrm{kg}$ MEA and $0.51 \mathrm{~mol} \mathrm{CO}_{2} / \mathrm{mol}$ MEA were obtained at the conditions of $5 \mathrm{~L} / \mathrm{min}$ gas flow rate, $25^{\circ} \mathrm{C}$ and $20 \%$ MEA concentration. This value is comparable to the values obtained in the literature.

It can be concluded that capture of $\mathrm{CO}_{2}$ into the MEA solution at bubble column can be successfully achieved with the high absorption capacity. Development of a solvent for a high absorption capacity is one of the most crucial issues for post-combustion capture. Mixed amine solutions can be used to achieve high absorption capacity.

Author contributions: All co-authors have involved in all stages of this study while preparing the final version. They all agree with the results and conclusions.

Funding: This study was supported by the Research Fund of Eskisehir Technical University (Project No: 1706F386).

Declaration of interest: The authors declare that they have no competing interests.

Ethics approval and consent to participate: Not applicable.

Availability of data and materials: All data generated or analyzed during this study are available for sharing when appropriate request is directed to corresponding author.

\section{REFERENCES}

Aronu, E. U., Gondal, S., Hessen, E. T., et al. (2011). Solubility of $\mathrm{CO}_{2}$ in $15,30,45$ and 60 mass\% MEA from 40 to $120^{\circ} \mathrm{C}$ and model representation using the extended UNIQUAC framework. Chemical Engineering Science, 66(24), 63936406. https://doi.org/10.1016/j.ces.2011.08.042

Bai, H. and Yeh, A. (1997). Removal of $\mathrm{CO}_{2}$ greenhouse gas by ammonia scrubbing. Industrial \& Engineering Chemistry Research, 36, 2490-2493. https://doi.org/10.1021/ie960748j

$\mathrm{Bi}, \mathrm{Y}$. and Ju, Y. (2021). Design and analysis of $\mathrm{CO}_{2}$ cryogenic separation process for the new LNG purification cold box. International Journal of Refrigeration, 130, 67-75. https://doi.org/10.1016/j.ijrefrig.2021.05.036

Chen, C. P., Shi, W., Du, R. and Chen, V. (2008). Scrubbing of $\mathrm{CO}_{2}$ greenhouse gases, accompanied by precipitation in a continuous bubble-column scrubber. Industrial \& Engineering Chemistry Research, 47, 6336-6343. https://doi.org/10.1021/ie070324x 
Conway, W., Bruggink, S., Beyad, Y., Luo, W., et al. (2015). $\mathrm{CO}_{2}$ absorption into aqueous amine blended solutions containing monoethanolamine (MEA), N, Ndimethylethanolamine (DMEA), $\mathrm{N}, \quad \mathrm{N}-$ diethylethanolamine (DEEA) and 2-amino-2-methyl-1propanol (AMP) for post-combustion capture processes. Chemical Engineering Science, 126, 446-454. https://doi.org/10.1016/j.ces.2014.12.053

Elhambakhsh, A., Zaeri, R. M., Mehdipour, M. and Keshavarz, P. (2020). Synthesis of different modified magnetic nanoparticles for selective physical/chemical absorption of $\mathrm{CO}_{2}$ in a bubble column reactor. Journal of Environmental Chemical Engineering, 8(5), 104195. https://doi.org/ 10.1016/j.jece.2020.104195

Heydarifard, M., Ghaemi, A. and Shirvani, M. (2020). Numerical simulation of $\mathrm{CO}_{2}$ chemical absorption in a gasliquid bubble column using the space-time CESE method. Journal of Environmental Chemical Engineering, 8(5), 104111. https://doi.org/10.1016/j.jece.2020.104111

Heydarifard, M., Pashaei, H., Ghaemi, A. and Nasiri, M. (2018). Reactive absorption of $\mathrm{CO}_{2}$ into piperazine aqueous solution in a stirrer bubble column: Modeling and experimental. International Journal of Greenhouse Gas Control, 79, 91-116. https://doi.org/10.1016/j.ijggc. 2018.09.017

Judd, S. P., van den Broeke, L. J., Shurair, M., Kuti, Y. and Znad, H. (2015). Algal remediation of $\mathrm{CO}_{2}$ and nutrient discharges: A review. Water Research, 87, 356-366. https://doi.org/10.1016/j.watres.2015.08.021

Maceiras, R., Álvarez, E. and Ángeles Cancela, M. (2008). Effect of temperature on carbon dioxide absorption in monoethanolamine solutions. Chemical Engineering Journal, 138(1-3), 295-300. https://doi.org/10.1016/j.cej. 2007.05.049

Maneeintr, K., Idem, R. O., Tontiwachwuthikul, P. and Wee, A. G. H. (2009). Synthesis, solubilities, and cyclic capacities of amino alcohols for $\mathrm{CO}_{2}$ capture from flue gas streams. Energy Procedia, 1, 1327-1334. https://doi.org/10.1016/ j.egypro.2009.01.174

NASA. (2021). Climate. https://climate.nasa.gov/vital-signs/ carbon-dioxide/

Pang, Z., Jiang, S., Zhu, C., Ma, Y. and Taotao Fu, T. (2021). Mass transfer of chemical absorption of $\mathrm{CO}_{2}$ in a serpentine mini channel. Chemical Engineering Journal, 414,12879. https://doi.org/10.1016/j.cej.2021.128791
Pashaei, H., Zarandi, M. N. and Ghaemi, A. (2017). Experimental study and modeling of $\mathrm{CO}_{2}$ absorption into diethanolamine solutions using stirrer bubble column. Chemical Engineering Research and Design, 121, 32-43. https://doi.org/10.1016/j.cherd.2017.03.001

Peng, Y., Zhao, B. and Li, L. (2012). Advance in postcombustion $\mathrm{CO}_{2}$ capture with alkaline solution: A brief review. Energy Procedia, 14, 1515-1522. https://doi.org/10.1016/j.egypro.2011.12.1126

Ramezani, R., Bernhardsen, M. I., Renzo Di Felice, R. D. and Knuutila, K. H. (2021). Physical properties and reaction kinetics of $\mathrm{CO}_{2}$ absorption into unloaded and $\mathrm{CO}_{2}$ loaded viscous monoethanolamine (MEA) solution. Journal of Molecular Liquids, 329, 115569. https://doi.org/10.1016/ j.molliq.2021.115569

Tan, L. S., Shariff, A. M., Lau, K. K. and Bustam, M. A. (2012). Factors affecting $\mathrm{CO}_{2}$ absorption efficiency in packed column: A review. Journal of Industrial and Engineering Chemistry, 18(6), 1874-1883. https://doi.org/10.1016/j.jiec. 2012.05.013

Wibowo, H., Susanto, H., Grisdanurak, N., Hantoko, D., et al. (2021). Recent developments of deep eutectic solvent as absorbent for $\mathrm{CO}_{2}$ removal from syngas produced from gasification: Current status, challenges, and further research. Journal of Environmental Chemical Engineering, 9(4), 105439. https://doi.org/10.1016/j.jece.2021.105439

Widakdo, J., Huang, T.-H., Subrahmanya, T. M., Faye, H., et al. (2021). Tailoring of graphene-organic frameworks membrane to enable reversed electrical-switchable permselectivity in $\mathrm{CO}_{2}$ separation. Carbon, 182, 545-558. https://doi.org/10.1016/j.carbon.2021.06.047

Wu, R., Ye, Q., Wu, K., Wang, L. and Dai, H. (2021). Highly efficient $\mathrm{CO}_{2}$ adsorption of corn kernel-derived porous carbon with abundant oxygen functional groups. Journal of $\mathrm{CO}_{2}$ Utilization, 51, 101620. https://doi.org/10.1016/j.jcou. 2021.101620

Yu, Y., Ma, Y., Yin, J., Zhang, C., Feng, G., Zhang, Y. and Meng, J. (2021). Tuning the micro-phase separation of the PES-gPEG comb-like copolymer membrane for efficient $\mathrm{CO}_{2}$ separation. Separation and Purification Technology, 265, 118465. https://doi.org/10.1016/j.seppur.2021.118465 